\title{
Pengaruh Manajemen Modal Kerja Terhadap Kinerja Keuangan Perusahaan Manufaktur di Indeks Saham Syariah
}

\author{
The influence of working capital management on financial performance of manufacturing in \\ the Indonesia sharia stock.
}

\section{Khoirun Nisa Nurul Muslimah}

Program Studi D4 Keuangan Syariah, Politeknik Negeri Bandung

Email: khoirun.nisa.ksy16@polban.ac.id

\section{Mochamad Edman Syarief}

Jurusan Akuntansi, Politeknik Negeri Bandung

Email: moch.edman@polban.ac.id

\begin{abstract}
This study aims to determine the effect of Working Capital Management as measured by the variables APP, ITO, ACP and CCC on the Financial Performance of Manufacturing Companies as measured by the variable ROA, ROE and EPS listed on the Sharia Stock Index for the 2015-2019 period. The population in this study uses a purposive sampling method with secondary data obtained from the annual financial statements of manufacturing companies registered at ISSI for the 2015-2019 period. This research uses descriptive analysis and path analysis using the WarpPLS 7.0 analysis tool. From this study, the results obtained that APP has a significant positive effect on ROA, ROE, and EPS. ITO has no significant effect on $\mathrm{ROA}$. ITO has a significant positive effect on $\mathrm{ROE}$ and EPS. ACP has a significant positive effect on $\mathrm{RO} A, \mathrm{ROE}$, and EPS. CCC bas no significant effect on $\mathrm{RO} A, \mathrm{ROE}$, and EPS. After a comparison between $A P P$ and $A C P$, it is known that in reality there are still operational activities of the company that are not in accordance with the applicable sharia provisions.
\end{abstract}

Keywords: Working Capital Management, Corporate Financial Performance, APP, ITO, $A C P, C C C, R O A, R O E$, EPS

\section{Pendahuluan}

Industri manufaktur memiliki kontribusi yang sangat besar bagi perkembangan perekonomian di Indonesia. Industri manufaktur mampu memberikan kontribusi kepada Produk Domestik Bruto (PDB) sebesar 20,38\%. Menurut BPS (2019) penyebab merosotnya pertumbuhan ekonomi RI sebagian besar karena kinerja sektor manufaktur yang kian merosot setiap tahunnya. Kontribusi sektor manufaktur dalam PDB tercatat paling besar namun pada tahun 2019 pertumbuhannya hanya diangka $3,80 \%$. Pencapaian tersebut masih lebih kecil dibandingkan tahun 2018 yaitu sebesar 4,27\%. Oleh karena itu, dengan kontribusi yang sangat besar namun pertumbuhan yang masih kurang perlu adanya perhatian khusus pada kinerja keuangan dalam memanajemen modal kerja perusahaan manufaktur di Indonesia.

Mengelola modal kerja sangatlah penting karena berpengaruh secara langsung pada profitabilitas dan risiko perusahaan, dan pada akhirnya akan berpengaruh pada nilai perusahaan itu sendiri (Smith, 1980; Antonius, 2013). Penelitian mengenai modal kerja menghasilkan dua pendapat yang berlawanan. Pendapat pertama mengatakan bahwa perusahaan perlu mempertahankan lebih sedikit investasi dalam modal kerja yang menghasilkan siklus konversi tunai atau cash convension cycle (CCC) yang lebih pendek. Pendapat lainnya mengatakan bahwa berinvestasi 
lebih banyak pada modal kerja akan menghasilkan CCC yang lebih lama.

Namun, kedua pendapat tersebut memiliki risiko masing-masing. Apabila suatu perusahaan memiliki investasi yang rendah pada modal kerja maka akan timbul risiko kehilangan penjualan dan juga gangguan dalam proses produksi. Begitupula apabila perusahaan memiliki investasi yang tinggi pada modal kerja maka akan timbul risiko kebangkrutan karena tingginya biaya yang harus dikelurkan dari investasi tersebut. (Banos-Caballero, 2013; Kieschinick, 2011) Kedua risiko tersebut akan menimbulkan masalah pada likuiditas perusahaan.

Oleh karena itu berdasarkan pertimbangan dari fakta-fakta yang telah disebutkan di atas dan dengan masalah yang kini dialami oleh Perusahaan Manufaktur di Indonesia maka Tugas Akhir ini akan membahas tentang pengaruh manajemen modal kerja terhadap kinerja keuangan Perusahaan Manufaktur di Indonesia khususnya pada Perusahaan Manufaktur yang terdaftar di Indeks Saham Syariah Periode 2015-2019. Berbeda dengan penelitian-penelitian sebelumnya, selain melihat pengaruh modal kerja terhadap kinerja keuangan, pada penelitian ini juga akan dilihat bagaimana manajemen modal kerja dalam perspektif syariah.

\section{Kajian Pustaka}

\subsection{Manajemen Modal Kerja}

Olfimarta \& Wibowo (2019) mengemukakan definisi dari manajemen modal kerja yang merupakan aktivitas yang mencakup segala fungsi manajemen meliputi aktiva lancar serta kewajiban jangka pendek suatu perusahaan. Tujuan manajemen modal kerja ialah memeriksa jalannya suatu perusahaan dalam melengkapi kewajiban jangka pendeknya dan mengetahui sejauh mana kegiatan perusahaan dapat didanai dari sumber pendanaan yang ada.

Perputaran modal kerja ialah salah satu bagian penting dalam manajemen keuangan. Menghitung perputaran modal kerja bergantung pada setiap komponen modal kerja yaitu perputaran kas, perputaran piutang dan perputaran persediaan. Secara umum suatu perusahaan harus mempertahankan aktiva lancar yang lebih besar dibandingkan dengan jumlah utang lancar, sehingga perputaran modal kerja tersebut dapat meningkat (Rahma, 2013).

Kas ialah salah satu faktor dari modal kerja yang sangat likuid, artinya semakin besar jumlah kas pada perusahaan maka akan semakin tinggi likuiditas dari perusahaan tersebut. Namun bukan berarti sebuah perusahaan harus memiliki jumlah kas yang banyak, karena semakin banyak jumlah kas yang tersedia maka akan menyebabkan banyaknya uang menganggur sehingga akan memperkecil keuntungan yang mungkin didapatkan. Jumlah kas pada perusahaan harus disesuaikan dengan kebutuhan perusahaan itu sendiri. Apabila suatu perusahaan tidak hanya mengejar keuntungan saja namun juga memperhatikan likuiditas perusahaannya, maka perusahaan tersebut akan dalam keadaan likuid apabila sewaktu-waktu ada tagihan (Riyanto, 2001; Olfimarta dan Wibowo, 2019).

Perputaran piutang ialah rasio aktivitas untuk menilai kemampuan suatu perusahaan dalam memakai dana yang ada yang akan tercermin dalam perputaran modal. Rasio perputaran piutang memberikan suatu gambaran yang berkaitan dengan kualitas dari piutang perusahaan serta memberikan gambaran seberapa berhasil perusahaan untuk menagih piutangnya. Semakin cepat perputaran piutang pada suatu perusahaan maka semakin efisien modal tersebut digunakan. (Olfimarta dan Wibowo, 2019).

Perputaran persediaan menunjukkan berapa kali dana yang tertanam pada persediaan berputar dalam satu periode. Semakin tinggi tingkat perputaran persediaan maka jumlah modal kerja terutama untuk investasi pada persediaan yang dibutuhkan semakin rendah. Hal tersebut akan memperkecil risiko terhadap kerugian yang diakibatkan karena adanya penurunan harga atau perubahan selera konsumen, disamping itu juga akan menghemat ongkos penyimpanan dan 
pemeliharaan terhadap persediaan tersebut (Bulan, 2015).

\subsection{Manajemen Modal Kerja Dalam Syariah}

Manajemen modal kerja ialah manajemen aktiva lancar dan passiva lancar. Dalam Islam, modal tidak boleh diabaikan. Artinya modal tersebut harus terus berputar. Setiap perusahaan harus mengupayakan dalam pengembangan modal, dengan tujuan untuk meningkatkan atau memperbanyak jumlah modal dengan cara yang halal dan sesuai dengan syariah Islam.

Semua manusia memiliki hak kepemilikan, akan tetapi bukan pemilik yang sebenarnya karena pemilik sebenarnya mutlak milik Allah SWT (Triono, 2014). Setiap manusia diperintahkan untuk selalu memperhatikan harta yang telah dianugerahkan oleh Allah SWT kepadanya, apakah dalam harta tersebut terdapat hak orang lain atau tidak. Apabila ada hak orang lain, maka setiap manusia diperintahkan untuk mengeluarkan hak tersebut dalam bentuk sedekah wajib yaitu zakat. Agar harta yang mereka miliki senantiasa dalam bentuk keberkahan.

Adapun manfaat apabila harta tidak beredar pada orang kaya saja yaitu :

1. Ekonomi merata

2. Tidak terjadi penggelembungan harta

3. Kestabilan ekonomi

4. Mencegah tindakan kriminal (Santoso, 2016).

Utang diperbolehkan dalam Islam, namun terdapat syarat-syarat yang harus terpenuhi. Berutang hanya dianjurkan dalam keadaan yang sangat mendesak. Kebiasaan seseorang berutang walaupun dalam situasi yang tidak mendesak hanya akan memberikan dampak buruk saja. Terutama apabila utang tersebut tidak sempat untuk dilunasi karena yang berutang lebih dulu meninggal dunia. Berutang memang diperbolehkan dalam Islam, namun lebih baik untuk menghindarinya. Rezeki setiap makhluk telah diatur oleh Allah SWT, tinggal bagaimana setiap makhluk tersebut menjemput dan mengelola rezeki yang telah diberikan dengan cara yang halal. Apabila memang seseorang berada dalam keadaan sangat mendesak untuk berutang, maka berutang lebih baik dilakukan dibandingkan dengan melakukan maksiat seperti mencuri. Namun saat berutang harus didasari dengan tujuan untuk dimanfaatkan sebaik-baiknya. Serta sudah diniati untuk melunasi utang tersebut secepat-cepatnya agar tidak menjadi penghambat di akhirat nanti.

Memberikan pinjaman diperbolehkan dalam ajaran agama Islam karena bagian dari kegiatan tolong menolong sesama manusia (hablun minan naas), sebagaimana dijelaskan dalam Q.S. AlMaidah (5):2 yaitu "Dan tolong menolonglah kamu dalam kebaikan dan takwa, dan janganlah kamu tolong menolong dalam melakukan kejahatan dan kerusakan". Tidak ada larangan untuk memberikan utang kepada pihak yang membutuhkan, bahkan hal tersebut sangat dianjurkan karena dapat membantu seseorang dari kesulitan yang sedang dihadapi. Disaat kita memberi utang kita juga berkewajiban untuk mengingatkan orang yang berutang untuk membayar utangnya.

Setiap manusia secara individu maupun kelompok membutuhkan persediaan untuk memenuhi segala kebutuhan dan mencegah resiko yang mungkin terjadi di masa yang akan datang. Namun bukan berarti setiap manusia tersebut berhak untuk menimbun persediaan, dalam arti lain menyimpan secara berlebihan. Banyaknya persediaan yang disediakan hanya sebatas pada seberapa banyak yang dibutuhkan, agar persediaan tersebut dapat dimanfaatkan oleh pihak lain yang membutuhkan.

Menimbun sesuatu demi mencari keuntungan pribadi hukumnya adalah dosa. Beberapa ulama memiliki pendapat bahwa kegiatan penimbunan tidak hanya berlaku pada bahan pokok seperti makanan saja, namun kebutuhan lain seperti pakaian juga tidak diperbolehkan. Larangan penimbunan disampaikan oleh Rasulullah SAW karena akan berpotesi merugikan banyak orang sehingga hanya akan menguntungkan sekelompok orang saja. Maka kita tidak boleh melakukan penimbunan pada persediaan, perputaran persediaan harus dikelola dengan baik agar tidak ada 
pihak yang dirugikan (kumparan, 2020).

Kinerja keuangan ialah suatu analisis yang digunakan untuk menilai sejauh mana perusahaan telah melaksanakan aturan-aturan keuangan dengan baik dan benar. Untuk melihat suatu gambaran mengenai kondisi keuangan perusahaan dapat dilihat dari kinerja perusahaan yang dapat dianalisis dengan alat-alat analisis keuangan, sehingga dapat diketahui bagaimana baik buruknya keadaan keuangan perusahaan tersebut. Kinerja keuangan perusahaan tersebut mencerminkan prestasi kerja perusahaan selama periode tertentu. Hal tersebut sangat penting bagi setiap perusahaan agar sumber daya dapat digunakan secara optimal untuk menghadapi perubahan dari lingkungan (Fahmi, 2011).

\section{Metode Penelitian}

Metode penelitian yang digunakan merupakan metode penelitian kuantitatif karena data yang diolah merupakan data yang dapat dikonversi menjadi angka. Data yang digunakan merupakan data sekunder berupa data panel dalam periode tahunan. Data panel yaitu data yang memiliki jumlah crossection dan jumlah time series. Sumber data didapat dari laporan keuangan yang dipublikasikan pada website wnw.idnfinancial.com.

Teknik sampel yang digunakan dalam penelitian ini yaitu purposive sampling yang merupakan suatu teknik penentuan sampel dengan pertimbangan karakteristik dan kriteria tertentu yang telah ditentukan (Basuki dan Yuliadi, 2015). Kriteria yang digunakan adalah perusahaan pada industri manufaktur yang terdaftar di Indeks Saham Syariah (ISSI) pada tahun 2019 yang terdaftar di JII pada Desember 2019-Juli 2020 dan mempublikasikan laporan keuangannya secara lengkap pada periode tahun 2015-2019.

Variabel independen pada penelitian ini yaitu Manajemen Modal Kerja/Working Capital Management (WCM) yang diukur dengan Perputaran Persediaan/Inventory Turnover (ITO), Siklus Konversi Tunai/Cash Convention Cycle (CCC), Periode Pengumpulan Rata-Rata/Average Collection Period (ACP), dan Periode Pembayaran Rata-Rata/Average Payment Period (APP). Variabel dependen pada penelitian ini yaitu Kinerja Keuangan Perusahaan/Financial Performance (FP) yang diukur dengan Return on Asset (ROA), Return on Equity (ROE) dan Earning Per Share (EPS).

Metode analisis yang digunakan untuk memecahkan permasalahan pada penelitian ini ialah metode analisis deskriptif dan analisis jalur dengan menggunakan program (software) WarpPLS versi 7.0.

\section{Hasil dan Pembahasan}

Tabel 1 Hasil Analisis Deskriptif

\begin{tabular}{|c|c|c|c|c|c|c|c|}
\hline & ROA & ROE & EPS & APP & ITO & ACP & CCC \\
\hline Mean & 0.09 & 0.144 & 297.924 & 814.768 & 2982.81 & 4515.37 & 2205.49 \\
\hline SD & 0.042 & 0.052 & 268.783 & 1244.73 & 786.296 & 2169.03 & 1508.18 \\
\hline Min & 0.002 & 0.004 & -0.001 & 0 & 1646.12 & 1391.98 & -1491.3 \\
\hline Max & 0.165 & 0.235 & 1183.48 & 4843.7 & 4447.82 & 8192.83 & 4338.51 \\
\hline Median & 0.079 & 0.15 & 293.5 & 330.906 & 2852.77 & 3969.77 & 2244.56 \\
\hline
\end{tabular}

Sumber : Data diolah oleh penulis, 2020

Variable Return on Asset (ROA) memiliki nilai rata-rata sebesar 0,09 dan nilai tengah sebesar 0,079. Nilai Return on Asset (ROA) paling tinggi yaitu sebesar 0,165. Sedangkan nilai Return on Asset (ROA) paling rendah yaitu sebesar 0,002. Nilai Standar Deviasi dari Return on Asset (ROA) yaitu sebesar 0,042. Variable ROE (Return on Equity) memiliki nilai rata-rata sebesar 0,144 dan nilai tengah sebesar 0,148. Nilai ROE (Return on Equity) paling tinggi yaitu sebesar 0,235. Sedangkan nilai ROE 
(Return on Equity) paling rendah yaitu sebesar 0,004. Nilai Standar Deviasi dari ROE (Return on Equity) yaitu sebesar 0,052.

Variable EPS (Earning Per Share) mempunyai nilai rata-rata sebesar 297,924 dan nilai tengah sebesar 293,5. Nilai EPS (Earning Per Share) paling tinggi yaitu sebesar 1183,48. Sedangkan nilai EPS (Earning Per Share) paling rendah sebesar -0,001. Nilai Standar Deviasi dari EPS (Earning Per Share) yaitu sebesar 268.783. Variable APP (Average Payment Period) mempunyai nilai rata-rata sebesar 814.768 dan nilai tengah sebesar 330.906. Nilai APP (Average Payment Period) paling tinggi yaitu sebesar 4843.7. Sedangkan nilai APP (Average Payment Period) paling rendah sebesar 0. Nilai Standar Deviasi dari APP (Average Payment Period) yaitu sebesar 1244.73.

Nilai rata-rata Variable ITO (Inventory Turnover) yaitu sebesar 2982.81 dan nilai tengah sebesar 2852.77. Nilai ITO (Inventory Turnover) paling tinggi yaitu sebesar 4447.82. Sedangkan nilai ITO (Inventory Turnover) paling rendah yaitu sebesar 1646.12. Nilai Standar Deviasi dari ITO (Inventory Turnover) yaitu sebesar 786.296. Variable ACP (Average Collection Period) memiliki nilai ratarata sebesar 4515.37 dan nilai tengah sebesar 3969.77. Nilai ACP (Average Collection Period) paling tinggi yaitu sebesar 8192.83. Sedangkan nilai ACP (Average Collection Period) paling rendah dimiliki oleh perusahaan PT Barito Pacific Tbk pada tahun 2019 yaitu sebesar 1391.98. Nilai Standar Deviasi dari ACP (Average Collection Period) yaitu sebesar 2169.03.

Variable CCC (Cash Convention Cycle) memiliki nilai rata-rata sebesar 2205.49 dan nilai tengah sebesar 2244.56. Nilai CCC (Cash Convention Cycle) paling tinggi yaitu sebesar 4338.51. Sedangkan nilai CCC (Cash Convention Cycle) paling rendah yaitu sebesar -1491.3. Nilai Standar Deviasi dari CCC (Cash Convention Cycle) yaitu sebesar 1508.18.

Tabel 2 Hasil Uji Goodness of Fit Model

\begin{tabular}{|c|c|c|c|}
\hline Index & Krite ria & Nilai & Keterangan \\
\hline Average Path Coefficient (APC) & P-0.05 & $0.272, \mathrm{p}=0.015$ & Diterima \\
\hline Average R-Square (ARS) & P-0.05 & $0.173, \mathrm{P}=0.061$ & $\begin{array}{c}\text { Tidak } \\
\text { diterima }\end{array}$ \\
\hline Average Adj R-Square (AARS) & P-0.05 & $0.079, \mathrm{P}=0.153$ & $\begin{array}{c}\text { Tidak } \\
\text { diterima }\end{array}$ \\
\hline Average Block VIF (AVIF) & Acceptable if -5, ideally -3.3 & 4.457 & Diterima \\
\hline Average Full Collinearity VIF (AFVIF) & Acceptable if -5, ideally -3.3 & 5475.954 & $\begin{array}{c}\text { Tidak } \\
\text { diterima }\end{array}$ \\
\hline Tenenhaus GOF (GOF) & Small -0.1, medium -0.25, large -0.36 & 0.416 & $\begin{array}{c}\text { Large, } \\
\text { Diterima }\end{array}$ \\
\hline Sympson's Paradox Ratio (SPR) & Acceptable if -0.7, ideally - 1 & 0.5 & $\begin{array}{c}\text { Tidak } \\
\text { diterima }\end{array}$ \\
\hline $\begin{array}{c}\text { R-Squared Contribution Ratio (RSCR) } \\
\text { diterima }\end{array}$ \\
\hline Statistical Suppression Ratio (SSR) & Acceptable if -0.9, ideally - & 0.679 & Diterima \\
\hline Nonlinesar Bivariate Causality Direction Ratio & Acceptable if - 0.7 & 1 & Diterima \\
\hline
\end{tabular}

Sumber : Data diolah oleh penulis, 2020

Kriteria Goodness of Fit bersifat rule of thumb, sehingga selayaknya tidak berlaku secara kaku dan mutlak. Apabila terdapat indikator Model Fit and Quality Indices yang tidak memenuhi kriteria maka model masih bisa digunakan. Indikator model fit tergantung pada tujuan dari analisis WarpPLS itu sendiri. Apabila tujuan penelitian hanya untuk pengujian hipotesis hubungan antar variabel laten maka indikator model fit menjadi kurang penting. Namun, apaila tujuannya menentukan model terbaik dari beberapa model yang berbeda (competing models) maka indeks fit sangat penting (Solimun dan Nurjannah, 2017) Mengingat bahwa tujuan dari penelitian ini adalah 
untuk menguji hipotesis antar variabel, maka tidak ada ketentuan khusus mengenai nilai GoF yang disyaratkan. Meskipun pada tabel di atas terlihat bahwa tidak semua ukuran memiliki nilai diatas cut-off value, namun dapat dikatakan bahwa model dapat digunakan untuk menguji hipotesis yang ditetapkan (Kock, 2020).

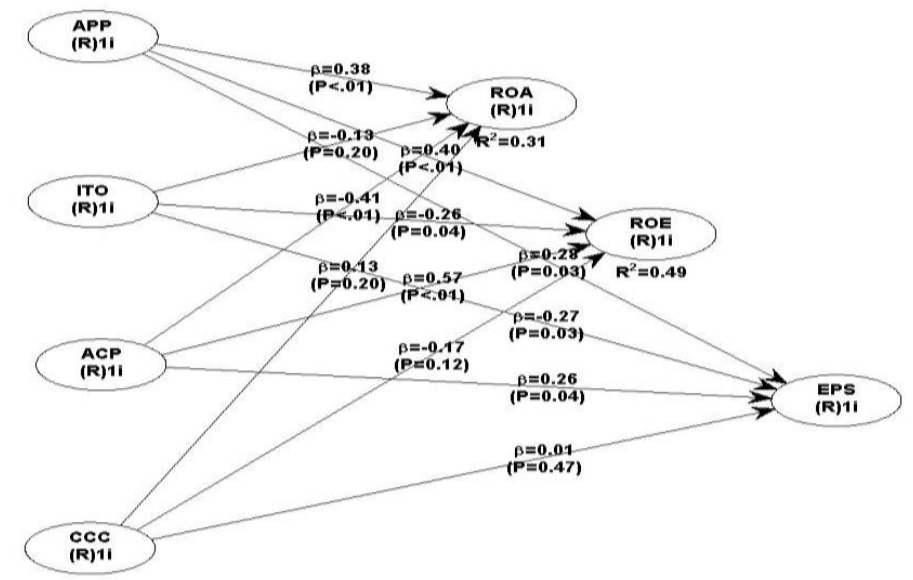

Gambar 1 Pengembangan Path Diagram atau Analisis Jalur

Sumber : Data diolah oleh penulis, 2020

\section{Hipotesis 1a}

Pengaruh Average Payment Period (APP) secara keseluruhan terhadap Return on Asset (ROA) signifikan, dengan nilai koefisien jalur sebesar 0,38 dan p-value $<0,01$. Karena p-value $<0,05$ maka H1 diterima. Average Payment Period (APP) secara keseluruhan berpengaruh langsung terhadap Return on Asset (ROA).

\section{Hipotesis 1b}

Pengaruh Average Payment Period (APP) secara keseluruhan terhadap Return on Equity (ROE) signifikan, dengan nilai koefisien jalur sebesar 0,40 dan p-value $<0,01$. Karena p-value $<0,05$ maka H1 diterima. Average Payment Period (APP) secara keseluruhan berpengaruh langsung terhadap Return on Equity (ROE).

\section{Hipotesis 1c}

Pengaruh Average Payment Period (APP) secara keseluruhan terhadap Earning Per Share (EPS) signifikan, dengan nilai koefisien jalur sebesar 0,28 dan p-value 0,03. Karena p-value $<0,05$ maka H1 diterima. Average Payment Period (APP) secara keseluruhan berpengaruh langsung terhadap Earning Per Share (EPS).

\section{Hipotesis 2a}

Pengaruh Inventory Turnover (ITO) secara keseluruhan terhadap Return on Asset (ROA) tidak signifikan, dengan nilai koefisien jalur sebesar 0,13 dan p-value 0,20. Karena p-value $>0,05$ maka H0 diterima. Inventory Turnover (ITO) secara keseluruhan berpengaruh tidak langsung terhadap Return on Asset (ROA).

\section{Hipotesis 2b}

Pengaruh Inventory Turnover (ITO) secara keseluruhan terhadap Return on Equity (ROE) signifikan, dengan nilai koefisien jalur sebesar 0,26 dan p-value 0,04. Karena p-value <0,05 maka H1 diterima. Inventory Turnover (ITO) secara keseluruhan berpengaruh langsung terhadap Return on Equity (ROE).

\section{Hipotesis 2c}


Pengaruh Inventory Turnover (ITO) secara keseluruhan terhadap Earning Per Share (EPS) signifikan, dengan nilai koefisien jalur 0,27 dan p-value 0,03. Karena p-value $<0,05$ maka H1 diterima. Inventory Turnover (ITO) secara keseluruhan berpengaruh langsung terhadap Earning Per Share (EPS).

\section{Hipotesis 3a}

Pengaruh Average Collection Period (ACP) secara keseluruhan terhadap Return on Asset (ROA) tidak signifikan, dengan nilai koefisien jalur sebesar 0,41 dan $\mathrm{p}$-value $<0,01$. Karena $\mathrm{p}$-value $<0,05$ maka H1 diterima. Average Collection Period (ACP) secara keseluruhan berpengaruh langsung terhadap Return on Asset (ROA).

\section{Hipotesis $3 b$}

Pengaruh Average Collection Period (ACP) secara keseluruhan terhadap Return on Equity (ROE) signifikan, dengan nilai koefisien jalur sebesar 0,57 dan p-value $<0,01$. Karena p-value $<0,05$ maka H1 diterima. Average Collection Period (ACP) secara keseluruhan berpengaruh langsung terhadap Return on Equity (ROE).

\section{Hipotesis 3c}

Pengaruh Average Collection Period (ACP) secara keseluruhan terhadap Earning Per Share (EPS) signifikan, dengan nilai koefisien jalur sebesar 0,26 dan p-value 0,04. Karena p-value <0,05 maka H1 diterima. Average Collection Period (ACP) secara keseluruhan berpengaruh langsung terhadap Earning Per Share (EPS).

\section{Hipotesis 4a}

Pengaruh Cash Convention Cycle (CCC) secara keseluruhan terhadap Return on Asset (ROA) tidak signifikan, dengan nilai koefisien jalur sebesar 0,13 dan p-value 0,20. Karena p-value $>0,05$ maka H0 diterima. Cash Convention Cycle (CCC) secara keseluruhan berpengaruh tidak langsung terhadap Return on Asset (ROA).

\section{Hipotesis 4b}

Pengaruh Cash Convention Cycle (CCC) secara keseluruhan terhadap Return on Equity (ROE) signifikan, dengan nilai koefisien jalur sebesar 0,17 dan p-value 0,12. Karena p-value $>0,05$ maka H0 diterima. Cash Convention Cycle (CCC) secara keseluruhan berpengaruh tidak langsung terhadap Return on Equity (ROE).

\section{Hipotesis 4c}

Pengaruh Cash Convention Cycle (CCC) secara keseluruhan terhadap Earning Per Share (EPS) signifikan, dengan nilai koefisien jalur sebesar 0,01 dan p-value 0,47. Karena p-value >0,05 maka H0 diterima. Cash Convention Cycle (CCC) secara keseluruhan berpengaruh tidak langsung terhadap Earning Per Share (EPS).

\section{Pengaruh Average Payment Period (APP) terhadap Return On Asset (ROA)}

Berdasarkan hasil output WarpPLS, hasil dari penelitian pada model ini menunjukkan bahwa variabel Average Payment Period (APP) berpengaruh positif signifikan terhadap variabel Return on Asset (ROA). Hasil tersebut ditunjukkan oleh nilai path coefficient yaitu sebesar 0,38 dan nilai pvalue sebesar $<0,01$. Adanya pengaruh positif signifikan pada Average Payment Period (APP) terhadap Retum on Asset (ROA) menunjukkan bahwa cepatnya periode pembayaran utang yang dilakukan oleh perusahaan manufaktur yang terdaftar di ISSI pada periode 2015-2019 dapat meningkatkan keuntungan perusahaan sehingga berpengaruh pada kinerja keuangan perusahaan. Nilai p-value APP yang rendah mengindikasikan bahwa semakin cepat waktu bagi perusahaan untuk membayar utang usaha atas pembelian bahan bakunya. Semakin sedikit waktu yang diperlukan maka perusahaan tersebut memiliki ketersediaan dana untuk membayar utang usahanya. Selain itu, 
perusahaan juga akan mendapatkan potongan pembelian karena melunasi utangnya sebelum jatuh tempo.

Setelah melunasi utangnya maka perusahaan akan melakukan pembelian kembali bahan baku untuk kegiatan produksi yang akan mereka jual. Hal tersebut mengindikasikan bahwa permintaaan akan barang tersebut meningkat dan penjualan perusahaan juga akan meningkat, sehingga tingkat profitabilitas perusahaan akan meningkat. Dengan hasil tersebut maka perusahaan pada penelitian ini telah menjalankan kegiatan usahanya sesuai syariah, karena perusahaan tersebut membayar hutangnya secara cepat sehingga mampu meningkatkan ROA perusahaan. Penelitian ini didukung oleh Harapan dkk. (2016), Sidabutar dkk (2017) dan Eforis dkk (2020) yang menyatakan APP berpengaruh positif signifikan terhadap ROA. Hasil penelitian ini tidak sesuai dengan penelitian yang dilakukan oleh Bagh dkk. (2016) yang menyebutkan terdapat pengaruh negatif antara Average Payment Period (APP) dengan Return on Asset (ROA). Hal ini dikarenakan masih rendahnya nilai APP yang digunakan oleh perusahaan pada penelitian tersebut untuk membiayai kegiatan yang dapat meningkatkan profitabilitas perusahaan.

\section{Pengaruh Average Payment Period (APP) terhadap Return On Equity (ROE)}

Berdasarkan hasil output WarpPLS, hasil dari penelitian pada model ini menunjukkan bahwa variabel Average Payment Period (APP) berpengaruh positif signifikan terhadap variabel Return on Equity (ROE). Hasil tersebut ditunjukkan oleh nilai path coefficient yaitu sebesar 0,40 dan nilai pvalue sebesar $<0,01$. Terdapat pengaruh positif signifikan pada Average Payment Period (APP) terhadap Return on Equity (ROE) pada perusahaan manufaktur yang terdaftar di ISSI pada periode 2015-2019 menunjukkan bahwa modal perusahaan tersebut terikat pada utang, artinya perusahaan dalam menjalankan kegiatan usahanya lebih banyak didanai oleh utang yang dapat meningkatkan tingkat keuntungan perusahaan sehingga berpengaruh pada peningkatan kinerja keuangan perusahaan. Menurut Umar dan Setiawan (2020) perusahaan-perusahaan manufaktur kriteria Syariah dengan proporsi utang yang lebih besar dalam struktur modal mereka, memiliki kinerja pasar yang lebih tinggi. Hasil penelitian ini didukung oleh hasil penelitian Kumaraswamy (2016) yang menyatakan adanya pengaruh positif signifikan pada variabel Average Payment Period (APP) terhadap Return on Equity (ROE).

Dengan hasil p-value sebesar $<0,01$, artinya perusahaan pada penelitian ini telah menjalankan kegiatan usahanya sesuai syariah, karena semakin cepat perusahaan tersebut membayarkan utangnya sehingga dapat meningkatkan Return on Equity (ROE) perusahaan. Hasil penelitian ini tidak didukung oleh Bagh dkk. (2016), yang memiliki hasil berlawanan yaitu tidak adanya pengaruh positif signifikan pada variabel Average Payment Period (APP) terhadap Return on Equity (ROE), karena pada penelitian tersebut modal yang digunakan untuk menjalankan operasional perusahaan sebagian besar tidak bersumber dari utang.

\section{Pengaruh Average Payment Period (APP) terhadap Earning Per Share (EPS)}

Berdasarkan hasil output WarpPLS, hasil dari penelitian pada model ini menunjukkan bahwa variabel Average Payment Period (APP) berpengaruh positif signifikan terhadap variabel Earning Per Share (EPS). Hasil tersebut ditunjukkan oleh nilai path coefficient yaitu sebesar 0,27 dan nilai p-value sebesar $<0,05$. Adanya pengaruh positif signifikan pada variabel Average Payment Period (APP) terhadap variabel Earning Per Share (EPS), menjelaskan bahwa pada penelitian ini lama ratarata waktu pembayaran utang yang dilakukan oleh perusahaan manufaktur yang terdaftar di ISSI pada periode 2015-2019 dapat meningkatkan laba per-saham sehingga berpengaruh pada peningkatan kinerja keuangan perusahaan. Hal tersebut dikarenakan adanya peningkatan tingkat profitabilitas perusahaan yang menyebabkan peningkatan pada nilai saham yang beredar pada perusahaan.

Nilai p-value sebesar $<0,05$ mengindikasikan bahwa perusahaan pada penelitian ini telah 
menjalankan usahanya sesuai syariah yang berlaku karena utang dibayarkan secara cepat dan dapat meningkatkan nilai EPS perusahaan. Hasil penelitian ini didukung oleh hasil penelitian Mudugba (2016) yang menyatakan adanya hubungan positif pada variabel Average Payment Period (APP) terhadap variabel Earning Per Share (EPS). Hasil penelitian ini tidak sesuai dengan penelitian yang dilakukan oleh Bagh dkk. (2016) yang menyebutkan terdapat pengaruh negatif pada variabel Average Payment Period (APP) terhadap variabel Earning Per Share (EPS). Penelitian tersebut menunjukkan kurangnya peningkatan profitabilitas perusahaan yang dipengaruhi oleh APP yang tidak menyebabkan peningkatan pada saham yang beredar pada perusahaan.

\section{Pengaruh Inventory Turnover (ITO) terhadap Return on Asset (ROA)}

Berdasarkan hasil output WarpPLS, hasil dari penelitian pada model ini menunjukkan bahwa variabel Inventory Turnover (ITO) tidak berpengaruh signifikan terhadap Return on Asset (ROA) pada perusahaan manufaktur yang terdaftar di ISSI tahun 2015-2019. Hal tersebut ditunjukkan oleh nilai p-value sebesar 0,20 yang tidak memenuhi kriteria signifikansi yaitu sebesar $<0,05$. Hasil tersebut dapat menjelaskan bahwa perusahaan belum mampu mengelola aktivanya dengan efisien karena belum mampu meningkatkan ROA sehingga kurang berpengaruh pada peningkatan kinerja keuangan perusahaan. Dalam arti lain menjelaskan bahwa perusahaan mencerminkan suatu investasi dengan tingkat pengembalian yang rendah.

Hasil dari penelitian ini menjelaskan bahwa pengaruh ITO pada ROA belum sesuai syariah karena di dalam syariah perputaran persedian yang baik adalah perputaran persediaan yang semakin cepat. Hasil ini didukung oleh hasil penelitian Gosh dan Maji (2003), Raheman dan Nasr (2007), Sharma dan Kumar (2011), dan Bagh dkk. (2016). Hasil penilitian ini tidak sesuai dengan hasil penelitian Kridasusila dkk (2016) yang menyatakan bahwa Inventory Turnover (ITO) berpengaruh positif signifikan terhadap Return on Asset (ROA). Hasil pada penelitian tersebut menjelaskan tingginya nilai ITO pada perusahaan yang menunjukkan kemampuan perusahaan mengontrol modal yang ada pada persediaan (inventory) semakin efisien, sehingga dapat meningkatkan tingkat profitabilitas perusahaan tersebut.

\section{Pengaruh Inventory Turnover (ITO) terhadap Return On Equity (ROE)}

Berdasarkan hasil output WarpPLS, hasil dari penelitian pada model ini menunjukkan bahwa variabel Inventory Turnover (ITO) berpengaruh positif signifikan terhadap Return on Equity (ROE). Pengaruh positif signifikan tersebut ditunjukkan oleh nilai p-value sebesar 0,04 dan path coefficient yaitu sebesar 0,26 yang mengindikasikan bahwa rasio perputaran persediaan dapat meningkatkan profitabilitas perusahaan sehingga berpengaruh pada peningkatan kinerja keuangan perusahaan. Setiap peningkatan ataupun penurunan yang terjadi pada persediaan akan memberikan dampak secara langsung pada ROE perusahaan. Semakin tinggi Inventory Turnover (ITO) maka semakin cepat kembalinya dana yang tertanam pada persediaan tersebut sehingga akan menaikkan tingkat profitabilitas perusahaan (Jurizen, 2015).

Dari hasil tersebut menggambarkan bahwa perusahaan telah menjalankan usahanya sesuai ketentuan syariah yang berlaku karena semakin cepat perputaran persediaan pada perusahaan tersebut sehingga dapat meningkatkan ROE perusahaan. Hasil penelitian ini didukung oleh hasil penelitian Jurizen (2015) dan Susilawati (2017). Namun hasil tersebut tidak sejalan dengan hasil penelitian Ali dkk. (2011) dan Qureshi dkk. (2014) yang menyatakan bahwa variabel Inventory Turnover (ITO) tidak berpengaruh terhadap variabel Return on Equity (ROE). Pada penelitian ini menjelaskan bahwa semakin banyak jumlah rasio perputaran persediaan maka dapat mengurangi profitabilitas ROE dari perusahaan tersebut. Hasil ini mengindikasikan bahwa penjualan perusahaan meningkat namun perusahaan memiliki ekuitas yang terlalu besar sehingga menyebabkan penurunan ROE.

\section{Pengaruh Inventory Turnover (ITO) terhadap Earning Per Share (EPS)}


Berdasarkan hasil output WarpPLS, hasil dari penelitian pada model ini menunjukkan bahwa variabel Inventory Tumover (ITO) berpengaruh positif signifikan terhadap Earning Per Share (EPS). Hasil tersebut ditunjukkan oleh nilai p-value sebesar 0,03 dan nilai path coefficient yaitu sebesar 0,27 yang menjelaskan bahwa perusahaan manufaktur yang terdaftar di ISSI pada periode 20152019 menghasilkan penjualan berdasarkan persediaan yang dimilikinya. Semakin tingginya perputaran persediaan tersebut maka penjualan akan semakin tinggi, sehingga menyebabkan laba yang diperoleh oleh para investor semakin meningkat sehingga berpengaruh pada peningkatan kinerja keuangan perusahaan.

Berdasarkan hasil tersebut dapat diketahui bahwa perusahaan telah menjalankan usahanya sesuai ketentuan syariah yang berlaku karena perputaran persediaan pada perusahaan tersebut semakin cepat sehingga dapat meningkatkan EPS perusahaan. Hasil pada penelitian ini didukung oleh penelitian Hanafiah (2014). Hasil penelitian ini tidak didukung oleh hasil penelitian Khanqah dkk (2012) yang menjelaskan bahwa dalam penelitiannya ITO tidak memiliki pengaruh pada EPS karena jumlah saham yang beredar tidak sebanding dengan keuntungan penjualan yang meningkat, sehingga ttidak adanya pengaruh dari ITO terhadap EPS pada perusahaan tersebut.

\section{Pengaruh Average Collection Period (ACP) terhadap Return on Asset (ROA)}

Berdasarkan hasil output WarpPLS, hasil dari penelitian pada model ini menunjukkan bahwa variabel Average Collection Period (ACP) berpengaruh positif signifikan terhadap Return on Asset (ROA) dengan nilai p-value sebesar $<0,01$ dan path coefficient yaitu sebesar 0,41 . Hasil tersebut menunjukkan bahwa perusahaan manufaktur yang terdaftar di ISSI pada periode 2015-2019 memiliki ACP yang kecil sehingga semakin cepat piutang tersebut dikumpulkan. Semakin cepat piutang tersebut dikumpulkan maka menyebabkan kecilnya kemungkinan piutang tak tertagih dan menurunkan piutang macet sehingga dana akan cepat kembali pada perusahaan dan dapat berpengaruh pada peningkatan kinerja keuangan perusahaan.

Dana yang kembali secara optimal digunakan untuk membiayai kegiatan operasional perusahaan sehingga dapat meningkatkan tingkat profitabilitas perusahaan tersebut. Menurut Gill dkk (2010), collection period yang tidak memiliki pengaruh terhadap profitabilitas perusahaan menunjukkan kurang optimalnya penggunaan dana piutang dalam kegiatan operasional atau dana piutang perusahaan digunakan untuk menutup utang usaha perusahaan. Meskipun hasil penelitian menunjukkan semakin cepat piutang terkumpul dapat meningkatkan tingkat ROA, namun hasil tersebut belum sesuai dengan sistem syariah yang berlaku. Karena piutang yang terkumpul lebih lama merupakan kegiatan yang dianjurkan di dalam syariah. Hasil penelitian ini sesuai dengan hasil penelitian Bagh dkk. (2016). Namun tidak sesuai dengan hasil penelitian Astutik (2016) yang menyatakan bahwa variabel Average Collection Period (ACP) tidak berpengaruh terhadap profitabilitas perusahaan, karena perusahaan belum mampu menggunakan dana piutang dalam kegiatan operasional secara optimal.

\section{Pengaruh Average Collection Period (ACP) terhadap Return On Equity (ROE)}

Berdasarkan hasil output WarpPLS, hasil dari penelitian pada model ini menunjukkan bahwa variabel Average Collection Period (ACP) berpengaruh positif signifikan terhadap Return on Equity (ROE) dengan nilai p-value $<0,01$ dan path coefficient yaitu sebesar 0,57. Hasil penelitian ini menyatakan bahwa rata-rata perputaran piutang berpengaruh positif terhadap profitabilitas (ROE) sehingga berpengaruh pada peningkatan kinerja keuangan perusahaan. Semakin cepat piutang tersebut dikumpulkan maka akan mempengaruhi tingkat profitabilitas perusahaan, karena akan mengurangi risiko gagalnya penagihan piutang atau piutang tak tertagih.

Walaupun pada hasil penelitian tersebut menunjukkan semakin cepat piutang terkumpul dapat meningkatkan tingkat ROE, namun hasil tersebut belum sesuai dengan sistem syariah yang berlaku. Karena dalam syariah piutang yang terkumpul lebih lama merupakan kegiatan yang lebih 
dianjurkan.Hasil tersebut sesuai dengan penelitian Malik dkk (2014) dan Suminar (2015). Hasil penelitian ini tidak sesuai dengan hasil penelitian Juani dan Aini (2017) yang menyebutkan bahwa Average Collection Period (ACP) tidak berpengaruh signifikan terhadap Return on Equity (ROE). Faktor penyebab yaitu karena sisa hasil usaha yang dicapai perusahaan tersebut masih rendah, sedangkan perputaran piutangnya tinggi. Rendahnya sisa hasil usaha pada saat perputaran tinggi akibat dari besarnya biaya operasional perusahaan dan gaji karyawan yang tinggi.

\section{Pengaruh Average Collection Period (ACP) terhadap Earning Per Share (EPS)}

Berdasarkan hasil output WarpPLS, hasil dari penelitian pada model ini menunjukkan bahwa variabel Average Collection Period (ACP) berpengaruh positif signifikan terhadap Earning Per Share (EPS). Hal tersebut ditunjukkan oleh nilai p-value sebesar 0,04 dan nilai path coefficient yaitu sebesar 0,26. Dari hasil tersebut dapat disimpulkan bahwa semakin cepat piutang dari penjualan tersebut terkumpul maka akan menambah keuntungan saham yang beredar, karena risiko terjadinya gagal bayar semakin sedikit sehingga berpengaruh pada peningkatan kinerja keuangan perusahaan. Hasil penelitian ini sejalan dengan hasil penelitian Bagh dkk. (2016). Hasil penelitian menunjukkan semakin cepat piutang terkumpul dapat meningkatkan tingkat EPS, namun pada syariah hasil tersebut belum sesuai dengan sistem yang berlaku. Karena dalam syariah piutang yang terkumpul lebih lama merupakan kegiatan yang lebih dianjurkan.

\section{Pengaruh Cash Convention Cycle (CCC) terhadap Return on Asset (ROA)}

Berdasarkan hasil output WarpPLS, hasil dari penelitian pada model ini menunjukkan bahwa variabel Cash Convention Cycle (CCC) tidak berpengaruh signifikan terhadap Return on Asset (ROA) pada perusahaan manufaktur yang terdaftar di ISSI tahun 2015-2019. Hal tersebut ditunjukkan oleh nilai p-value sebesar 0,20 yang tidak memenuhi kriteria signifikansi yaitu sebesar $<0,05$ dan nilai path coefficient yaitu sebesar 0,13. Hasil tersebut menjelaskan bahwa CCC yang lebih baik adalah CCC yang lebih pendek. Sedangkan CCC yang dihasilkan pada penelitian ini merupakan CCC yang lebih panjang sehingga kurang berpengaruh pada peningkatan kinerja keuangan perusahaan. Semakin pendek waktu yang dibutuhkan dalam siklus konversi dana sampai masuk ke dalam kas perusahaan maka dapat meningkatkan tingkat profitabilitas perusahaan. Perusahaan dengan jangka waktu CCC yang lebih pendek akan menghasilkan keuntungan yang lebih besar dibandingkan dengan perusahaan yang memiliki jangka waktu CCC yang lebih panjang (Syarief dan Wilujeng, 2009).

Hasil pada penelitian tersebut tidak sesuai dengan syariah yang berlaku. Karena CCC yang dihasilkan bukan CCC yang pendek. Sedangkan dalam ketentuan syariah semakin cepat perputaran kas maka akan semakin baik. Artinya bahwa kas tersebut dapat terus berputar sehingga dapat mendatangkan manfaat bagi orang lain. Hasil penelitian ini didukung oleh hasil penelitian yang dilakukan oleh Bagh dkk (2016) dan Zhuquan (2015). Namun hasil penelitian ini tidak sesuai dengan hasil penelitian yang dilakukan oleh Bulin dkk. (2016) yang menyatakan terdapat pengaruh positif antara Cash Convention Cycle (CCC) terhadap Return on Asset (ROA).

\section{Pengaruh Cash Convention Cycle (CCC) terhadap Return On Equity (ROE)}

Berdasarkan hasil output WarpPLS, hasil dari penelitian pada model ini menunjukkan bahwa variabel Cash Convention Cycle (CCC) tidak berpengaruh signifikan terhadap Return on Equity (ROE) pada perusahaan manufaktur yang terdaftar di ISSI tahun 2015-2019. Hal tersebut ditunjukkan oleh nilai p-value sebesar 0,12 yang tidak memenuhi kriteria signifikansi yaitu sebesar $<0,05$ dan nilai path coefficient yaitu sebesar 0,17.

Penjelasan dari hasil tersebut sama dengan penjelasan CCC terhadap ROA, yaitu jangka waktu CCC yang lebih pendek akan menghasilkan keuntungan yang lebih besar pada perusahaan. Sedangkan hasil pada CCC pada penelitian ini lebih panjang sehingga tidak dapat mempengaruhi tingkat ROE sehingga kurang berpengaruh pada peningkatan kinerja keuangan perusahaan. 
Sehingga apabila dikaitkan dengan sistem syariah, CCC pada penelitian ini belum sesuai dengan ketentuan syariah yang berlaku karena CCC pada perusahaan tersebut memiliki hasil yang lebih panjang. Hasil penelitian ini didukung oleh hasil penelitian yang dilakukan oleh Bagh dkk. (2016) dan Zhuquan (2015).

\section{Pengaruh Cash Convention Cycle (CCC) terhadap Earning Per Share (EPS)}

Berdasarkan hasil output WarpPLS, hasil dari penelitian pada model ini menunjukkan bahwa variabel Cash Convention Cycle (CCC) tidak berpengaruh signifikan terhadap Earning Per Share (EPS). Hal tersebut ditunjukkan oleh nilai p-value sebesar 0,47 dan nilai path coefficient yaitu sebesar 0,01. Tidak terdapat pengaruh antara CCC dengan EPS disebabkan oleh jumlah peningkatan piutang, utang serta persediaan pada current asset. Kondisi ini menunjukkan adanya investasi secara berlebihan pada current assets yang menyebabkan perusahaan beroperasi kurang efisien sehingga menyebabkan kurangnya pengaruh pada peningkatan kinerja keuangan perusahaan. Hasil penelitian ini sama dengan hasil dari penelitian yang dilakukan oleh Gill dkk (2010). Hasil pada penelitian CCC terhadap EPS tidak sesuai dengan ketentuan syariah yang berlaku. Karena dalam ketentuan syariah semakin cepat perputaran kas maka akan semakin baik. Sedangkan CCC yang dihasilkan bukan CCC yang yang lebih pendek sehingga CCC pada perusahaan tidak berpengaruh pada peningkatan EPS.

\section{Manajemen Modal Kerja Dalam Perspektif Syariah}

Variabel yang digunakan dalam menghitung modal kerja pada penelitian ini yaitu variabel Average Payment Period (APP), Average Collection Period (ACP), Inventory Turnover (ITO) dan Cash Convention Cycle (CCC). Inventory Turnover (ITO) dan Cash Convention Cycle (CCC) memiliki ketentuan yang sama baik dalam konvensional maupun syariah. Semakin tinggi tingkat perputaran maka akan semakin baik. Sedangkan variabel Average Payment Period (APP) dan Average Collection Period (ACP) memiliki ketentuan yang berbeda antara konvensional dan syariah.

Tabel 3 Hasil Perbandingan APP dan ACP

\begin{tabular}{|c|c|c|c|c|c|c|c|c|c|c|c|}
\hline $\begin{array}{c}\text { Nama } \\
\text { Perusahaan }\end{array}$ & Tahun & APP & ACP & $\begin{array}{c}\text { Perban } \\
\text { dingan }\end{array}$ & Keterangan & $\begin{array}{c}\text { Nama } \\
\text { Perusahaan }\end{array}$ & Tahun & APP & $\mathbf{A C P}$ & $\begin{array}{r}\text { Perban } \\
\text { dingan }\end{array}$ & Keterangan \\
\hline ASII & 15 & 69.426 & 2359.06 & 0.58 & Tidak Sesuai Syariah & INDF & 2015 & 152 & 5129.261 & 0.08 & Tidak Ses \\
\hline ASII & & 5.638 & 2536.984 & 48 & Tidak Sesuai Syariah & & 2016 & & 5416.665 & 0.09 & Tidak Sesı \\
\hline ASII & 2017 & 4.0572 & 2386.421 & 0.42 & Tidak Sesuai Syariah & INDF & 2017 & 466.6258 & 5305.837 & 0.09 & Tidak Sesuai Syariah \\
\hline ASII & & 4.6132 & \begin{tabular}{|l|}
2135.119 \\
\end{tabular} & 0.37 & Tidak Sesuai Syariah & & & & 5131.169 & 0.05 & Tidak \\
\hline ASII & 2019 & 32.1979 & 1993.593 & 0.39 & Tidak Sesuai Syariah & INDF & 2019 & 83.56197 & 5173.282 & 0.02 & Tidak Sesuai Syariah \\
\hline BRPT & 15 & 784.746 & \begin{tabular}{|l|}
6654.187 \\
\end{tabular} & 0.12 & Tidak Sesuai Syariah & INTP & 2015 & 1.24293 & 5125.905 & 0.00 & Tidak Se \\
\hline BRPT & 2016 & \begin{tabular}{|l|}
159.0331 \\
\end{tabular} & \begin{tabular}{|l|}
7363.21 \\
\end{tabular} & 0.02 & Tidak Sesuai Syariah & INTP & 2016 & 0 & 2181.742 & 0.00 & Tidak Sesuai Syariah \\
\hline BRPT & 2017 & 31.6316 & \begin{tabular}{|l|}
5152.091 \\
\end{tabular} & 0.03 & Tidak Sesuai Syariah & INTP & 2017 & 2.752059 & 2069.652 & 0.00 & Tidak $\mathrm{S}$ \\
\hline BRPT & 2018 & 110.4718 & \begin{tabular}{|l|}
4017.449 \\
\end{tabular} & 0.03 & Tidak Sesuai Syariah & INTP & 2018 & 11.04134 & 2034.446 & 0.01 & Tidak Sesuai Syariah \\
\hline BRPT & 2019 & 68.86274 & \begin{tabular}{|l|}
1391.987 \\
\end{tabular} & 0.05 & Tidak Sesuai Syariah & INTP & 2019 & 179 & 1955.608 & 0.00 & Tidak Se \\
\hline CPIN & & 29 & 7330.35 & 0.05 & Tidak & JPFA & 2015 & 79.59732 & 7479.261 & 0.01 & yariah \\
\hline CPIN & & & \begin{tabular}{|l|}
5255.14 \\
\end{tabular} & 0.23 & Tidak Sesuai Syariah & JPFA & 2016 & 10.63724 & 8192.831 & 0.00 & i Syariah \\
\hline CPIN & 2017 & 4843.704 & \begin{tabular}{|l|}
7707.562 \\
\end{tabular} & 0.63 & Tidak Sesuai Syariah & JPFA & 2017 & 37.01341 & 7794.843 & 0.00 & Tidak Sesuai Syariah \\
\hline CPIN & & 4780.275 & \begin{tabular}{|l|}
7501.558 \\
\end{tabular} & 0.64 & Tidak Sesuai Syariah & JPFA & 2018 & 4.882883 & 7679.105 & 0.00 & Tidak Sesuai Syariah \\
\hline CPIN & 2019 & 4427.337 & 7353.058 & 0.60 & Tidak Sesuai Syariah & JPFA & 2019 & 26.67873 & 7326.793 & 0.00 & Tidak Sesuai Syariah \\
\hline ICBP & & 468.2685 & \begin{tabular}{|l|}
3922.101 \\
\end{tabular} & 0.12 & Tidak Sesuai Syariah & KLBF & 2015 & 1382.125 & 2777.249 & 0.50 & Tidak Sesuai Syariah \\
\hline ICBP & 2016 & 148.714 & 3636.376 & 0.04 & Tidak Sesuai Syariah & KLBF & 2016 & 1522.069 & 2836.589 & 0.54 & Tidak Sesuai Syariah \\
\hline ICBP & & 199.6278 & \begin{tabular}{|l|}
3423.503 \\
\end{tabular} & 0.06 & & KLBF & 2017 & & 2675.011 & 0.60 & ai Syariah \\
\hline ICBP & 2018 & 38.33931 & 3505.467 & 0.01 & Tidak Sesuai Syariah & KLBF & 2018 & 1543.812 & 2508.862 & 0.62 & Tidak Sesuai Syariah \\
\hline ICBP & 2019 & 0 & 3775.807 & 0.00 & Tidak Sesuai Syariah & KLBF & 2019 & 1767.125 & 2419.665 & 0.73 & Tidak Sesuai Syariah \\
\hline
\end{tabular}

Sumber : Data diolah oleh penulis, 2020

Di dalam syariah semakin cepat utang dibayar maka akan semakin baik dan semakin lama pitang ditagih maka akan semakin baik, namun di dalam konvensional ketentuan tersebut berlaku sebaliknya.Untuk mengetahui manakah periode perputaran yang lebih panjang maka dapat dihitung menggunakan perbandingan dengan syarat: 
APP : ACP $=>1$ (APP lebih besar daripada ACP yang berarti sesuai syariah)

APP : ACP $=<1$ (APP lebih kecil daripada ACP yang berarti belum sesuai syariah)

Dari hasil perbandingan tersebut dapat dilihat bahwa 8 perusahaan manufaktur yang terdaftar di ISSI periode 2015-2019 belum memenuhi ketentuan yang berlaku di dalam syariah Islam. Meskipun pada pembahasan sebelumnya didapatkan hasil bahwa semakin cepat Average Payment Period (APP) dan Average Collection Period (ACP) dapat memberikan pengaruh positif pada peningkatan kinerja keuangan, namun dalam Islam terdapat ketentuan yang berbeda. Lebih baik Average Payment Period (APP) yang lebih pendek dan Average Collection Period (ACP) yang lebih panjang. Namun hasil dari perbandingan tersebut memiliki hasil yang tidak sesuai dengan ketentuan syariah yang berlaku. Nilai Average Payment Period (APP) masih lebih panjang daripada Average Collection Period (ACP) yang artinya rata-rata periode pembayar utang lebih lama dibandingkan ratarata periode pembayaran piutang. Meskipun 8 perusahaan tersebut telah memenuhi persyaratan perusahaan syariah, namun pada kenyataannya masih ada kegiatan operasional yang belum sesuai dengan ketentuan syariah yang berlaku.

\section{Penutup}

Berdasarkan hasil dari penelitian yang telah dilakukan maka dapat ditarik kesimpulan sebagai berikut :

1) Manajemen modal kerja berpengaruh terhadap kinerja keuangan setelah diukur dengan hubungan variabel-variabel sebagai berikut :

a. Average Payment Period (APP) berpengaruh positif signifikan terhadap variabel Return on Asset (ROA) yang berarti bahwa semakin cepat perputaran pembayaran utang akan meningkatkan profitabilitas sehingga berpengaruh pada peningkatan kinerja keuangan perusahaan serta telah sesuai dengan ketentuan syariah.

b. Average Payment Period (APP) berpengaruh positif signifikan terhadap variabel Return on Equity (ROE) yang berarti bahwa perusahaan dalam menjalankan kegiatan usahanya lebih banyak didanai oleh utang yang dapat meningkatkan tingkat profitabilitas perusahaan sehingga berpengaruh pada peningkatan kinerja keuangan perusahaan serta telah sesuai dengan ketentuan syariah yang berlaku.

c. Average Payment Period (APP) berpengaruh positif signifikan terhadap variabel Earning Per Share (EPS) yang berarti bahwa lama rata-rata waktu pembayaran utang yang dilakukan oleh perusahaan dapat meningkatkan laba per-saham sehingga berpengaruh pada peningkatan kinerja keuangan perusahaan serta telah sesuai dengan ketentuan syariah yang berlaku.

d. Inventory Turnover (ITO) tidak berpengaruh terhadap Return on Asset (ROA) yang berarti bahwa perusahaan belum mampu mengelola aktivanya dengan efisien karena belum mampu meningkatkan ROA sehingga kurang berpengaruh pada peningkatan kinerja keuangan perusahaan serta belum sesuai dengan ketentuan syariah yang berlaku.

e. Inventory Turnover (ITO) berpengaruh positif signifikan terhadap Return on Equity (ROE) yang berarti bahwa rasio perputaran persediaan dapat meningkatkan profitabilitas perusahaan sehingga berpengaruh pada peningkatan kinerja keuangan perusahaan serta telah sesuai dengan ketentuan syariah yang berlaku.

f. Inventory Turnover (ITO) berpengaruh positif signifikan terhadap Earning Per Share (EPS) yang berarti bahwa perusahaan menghasilkan penjualan berdasarkan persediaan yang dimilikinya yang menyebabkan laba yang diperoleh oleh para investor semakin meningkat sehingga berpengaruh pada peningkatan kinerja keuangan perusahaan serta telah sesuai dengan ketentuan syariah yang berlaku.

g. Average Collection Period (ACP) berpengaruh positif signifikan terhadap Return on Asset (ROA) yang berarti bahwa semakin cepat perputaran piutang dapat meningkatkan tingkat 
profitabilitas perusahaan sehingga berpengaruh pada peningkatan kinerja keuangan perusahaan namun belum sesuai dengan ketentuan syariah yang berlaku.

h. Average Collection Period (ACP) berpengaruh positif signifikan terhadap Return on Equity (ROE) yang berarti bahwa hasil penelitian ini menyatakan bahwa rata-rata perputaran piutang berpengaruh positif terhadap profitabilitas (ROE) sehingga berpengaruh pada peningkatan kinerja keuangan perusahaan namun belum sesuai dengan ketentuan syariah yang berlaku.

i. Average Collection Period (ACP) berpengaruh positif signifikan terhadap Earning Per Share (EPS) yang berarti bahwa semakin cepat piutang dari penjualan tersebut terkumpul maka akan menambah keuntungan saham yang beredar sehingga berpengaruh pada peningkatan kinerja keuangan perusahaan namun belum sesuai dengan ketentuan syariah yang berlaku.

j. Cash Convention Cycle (CCC) tidak berpengaruh terhadap Return on Asset (ROA) yang berarti bahwa CCC yang lebih panjang tidak dapat meningkatkan keuntungan suatu perusahaan sehingga kurang berpengaruh pada peningkatan kinerja keuangan perusahaan serta belum sesuai dengan ketentuan syariah yang berlaku.

k. Cash Convention Cycle (CCC) tidak berpengaruh terhadap Return on Equity (ROE) yang berarti bahwa CCC yang lebih panjang tidak akan menghasilkan keuntungan yang lebih besar pada perusahaan sehingga kurang berpengaruh pada peningkatan kinerja keuangan perusahaan serta belum sesuai dengan ketentuan syariah yang berlaku.

1. Cash Convention Cycle (CCC) tidak berpengaruh terhadap Earning Per Share (EPS) yang berarti bahwa adanya investasi secara berlebihan pada current assets yang menyebabkan perusahaan beroperasi kurang efisien sehingga kurang berpengaruh pada peningkatan kinerja keuangan perusahaan serta belum sesuai dengan ketentuan syariah yang berlaku.

2) Dilihat dari hasil perbandingan Average Payment Period (APP) dan Average Collection Period (ACP) menunjukkan bahwa pada kenyataannya pada perusahaan manufaktur yang terdaftar di ISSI pada tahun 2015-2019 masih ada kegiatan operasional yang belum sesuai dengan ketentuan syariah yang berlaku.

Adapun beberapa saran yang berkaitan dengan pembahasan yang telah dilakukan sebelumnya yaitu sebagai berikut:

1) Perusahaan diharapkan dapat selalu membayarkan utangnya dengan cepat, karena semakin cepat utang dibayarkan maka dapat meningkatkan kinerja perusahaan serta sesuai dengan ketentuan syariah yang berlaku.

2) Perusahaan sebaiknya melakukan pengelolaan perputaran persediaan secara optimal dan efisien sehingga dapat meningkatkan tingkat pengembalian yang tinggi dan meningkatkan profitabilitas perusahaan sehingga berpengaruh pada peningkatan kinerja keuangan perusahaan dan sesuai dengan ketentuan syariah yang berlaku.

3) Walaupun Average Collection Period yang lebih cepat dapat meningkatkan kinerja perusahaan namun hendaknya perusahaan syariah memberikan tenggang waktu yang lebih lama bagi para peminjam yang sedang mengalami kesulitan, karena merupakan kegiatan yang dianjurkan untuk memberikan keringanan pada orang yang sedang kesulitan.

Dengan pengaruh yang diberikan oleh manajemen modal kerja terhadap kinerja keuangan perusahaan maka diharapkan manajemen modal kerja lebih diperhatikan oleh setiap perusahaan demi kemajuan perusahaan itu sendiri.

\section{Daftar Pustaka}

Ali, K., Akhtar, M. F., \& Sadaqat, S. (2011). Factors Influencing the Profitability of Islamic Banks of Pakistan. International Research Journal of Finance and Economics (66), 125-132.

Antonius, L. (2013). Pengaruh Manajemen Modal Kerja dan Rasio Keuangan Terhadap Profitabilitas Pada 
Industri Manufaktur Yang Terdaftar di Bursa Efek Indonesia (BEI) Tabun 2011. Semarang.

Astutik, E. P. (2016). Analisis Faktor-Faktor Profitabilitas Perusahaan Menggunakan Purposive Sampling dan Regresi Berganda. Jurnal Riset Akuntansi Terpadu, 105-108.

Badan Pusat Statistik. (2019). Pertumbuban Ekonomi Indonesia Triwulan IV -2019. Jakarta: Badan Pusat Stastik.

Bagh, T., \& al., e. (2016). The Impact of Working Capital Management on Firms Financia Performance: Evidence from Pakistan. International Journal of Economics and Financial Issues, 1097.

Banos-Caballero, S., Garcia-Teruel, P. J., \& Martinez-Solano, P. (2013). The Speed of Adjustment in Working Capital Requirement. The European Journal of Finance, 978-992.

Basuki, A. T., \& Yuliadi, I. (2015). Teori dan Aplikasi. Yogyakarta: Mitra Pustaka Matani.

Bulan, T. P. (2015). Pengaruh Modal Kerja terhadap Tingkat Profitabilitas pada PT Adira Dinamika Multi Finance Tbk. Jurnal Manajemen dan Keuangan, 305-316.

Bulin, S., Basit, A., \& Hamza, S. M. (2016). Impact of Working Capital Management. International Journal of Accounting \& Business Management, 227.

Eforis, C., \& Pioleta, G. (2020). Pengaruh Average Collection Period, Inventory Turnover In Days, Average Payment Period, Debt Ratio, Struktur Aset dan Ukuran Perusahaan Terhadap Profitabilitas Perusahaan. ULTIMA Management, 164-188.

Fahmi, I. (2011). Analisis Laporan Kenangan. Lampulo: ALFABETA.

Gill, A., Biger, N., \& Mathur, N. (2010). The Relationship Between Working Capital Management and Profitability: Evidance from The United States. Business and Economics Journal: 1-9.

Gosh, S. K., \& Maji, S. G. (2003). Working Capital Management Efficiency: A Study on The Indian Cement Industry.

Hanafiah, M. A. (2014). Pengaruh Current Ratio, Quick Ratio, Inventory Turnover, Total Aset Turnover, Debt to Equity Ratio Terhadap Earning Per Share Pada Perusahaan Industri Barang Konsumsi Yang Terdaftar Di Bursa Efek Indonesia Periode 2009-2012. e-Joumal Fakultas Ekonomi Universitas Maritim Raja Ali Haji.

Harapan, A., \& Prasetiono, H. (2016). Pengaruh Average Collection Period, Average Payment Period, Turnover in Days, Sales Growth dan Debt Ratio Terhadap Profitabilitas Perusahaan. Diponegoro Journal Of Management, 1-11.

Juani, M., \& Aini, N. (2017). Pengaruh TIngkat Perputaran Piutang Terhadap Profitabilitas Pada Koperasi Pondok Pesantren Al-Mukhlisin Desa Lepak Kecamatan Sakta Timur 2012-2016. JPEK, 130-140.

Jurizen. (2015). Pengaruh Inventory Turn Over dan Fixed Asset TUrn Over Terhadap Return on Equity Pada Perusahaan Farmasi Yang Terdaftar di BEI Tahun 2007-2013. Jurnal Kajian Manajemen Bisnis.

Jurizen. (2015). Pengaruh Inventory Turn Over dan Fixed Asset TUrn Over Terhadap Return on Equity Pada Perusahaan Farmasi Yang Terdaftar di BEI Tahun 2007-2013. Jurnal Kajian Manajemen Bisnis.

Khanqah, V. K., Khosroshahi, M. A., \& Ebrati, M. R. (2012). An Investigation of the Association between Working Capital Management and Corporate Performance. International Journal Management and Business, 203-218.

Kieschinick, R., LaPlante, M., \& Moussawi, R. (2011). Working Capital Management and Shareholder Wealth. Retrieved from Working Paper Available at SRRN: 
http:/ / ssrn.com/abstract $=1431165$

Kock, N. (2020). WarpPLS User Manual: Version 7.0. Texas: ScriptWarp Systems.

Kridasusila, A., \& Rachmawati, W. (2016). Analisis Pengaruh Current Ratio, Inventory Turn Over dan Debt To Equity Ratio Pada Perusahaan Otomotif dan Produk Komponennya Pada Bursa Efek Indonesia (2010-2013). Jurnal Dinamika Sosial Budaya, 7-22.

Kumaraswamy, S. (2016). Impact of Working Capital on Financial Performance of Gulf Cooperation Council Firms. International Journal of Economics and Financial Issues, 1136-1142.

Kumparan. (2020, Maret 31). kumparan. Retrieved Juli 30, 2020, from Hadis Tentang Larangan Menimbun Barang, Termasuk Saat Pandemi Corona: https://kumparan.com/berita-hariini/hadis-tentang-larangan-menimbun-barang-termasuk-saat-pandemi-corona-

1 t8ASanPe0V/full

Mai, M. U., \& Setiawan. (2020). Pengaruh Struktur Modal Terhadap Kinerja Perusahaan Pada Industri Manufaktur Kriteria Syariah Di Bursa Efek Indonesia. Jurnal Riset Akuntansi dan Keuangan, 159-170.

Malik, M., \& Bukhari, M. (2014). The Impact of Working Capital Management on Corporate Performance: A Study of Firms in Cement, Chemical \& Engineering Sectors of Pakistan. Pakistan Journal of Commerce and Social Science, 134-148.

Mudugba, J. U. (2016). Working Capital Management and Financial Performance: Evidaence From Manufacturing Companies in Nigeria. European Journal of Accounting, Auditing and Finance Research, 98-106.

Olfimarta, D., \& Wibowo, S. S. (2019). Manajemen Modal Kerja dan Kinerja Perusahaan pada Perusahaan Perdagangan Eceran di Indonesia. Journal of Applied Accounting and Taxation, 8799.

Olfimarta, D., \& Wibowo, S. S. (2019). Manajemen Modal Kerja dan Kinerja Perusahaan pada Perusahaan Perdagangan Eceran di Indonesia. Journal of Applied Accounting and Taxation, 8799.

Qureshi, M. A., \& Ahsar, T. W. (2014). Mean Reverting Financial Leverage and Firm Life Cucle: Theory versus Evidance (Pakistan). Emerging Economy Studies, 19-26.

Raheman, A., \& Nasr, M. (2007). Working Capital Management and Profitability-case of Pakistani Firms. International Journal of Advance Research, 1-10.

Rahma, A. (2013). Analisis Pengaruh Managemen Modal Kerja Terhadap Profitabilitas Perusahaan (Studi pada perusahaan PMA \& PMDN yang Listing di BEI periode 2004-2008).

Riyanto, B. (2001). Dasar-Dasar Pembelanjaan Perusahaan. Yogyakarta: BPFE.

Santoso, B. (2016, Mei 15). Harta Tidak Boleh Berkisar Pada Orang Kaya Saja. Retrieved Juli 30, 2020, from Ilmu dan Tsaqofah: http://ilmudantsaqofah.blogspot.com/2016/05/harta-tidakboleh-berkisar-pada-orang.html

Sharma, A., \& Kumar, S. (2011). Effect of Working Capital Management on Firm Profitability: Empirical Evidance from India. Global Business Review, 159-173.

Sidabutar, R. B., \& Widyarti, E. T. (2017). Analisis Pengaruh Manajemen Modal Kerja, Ukuran Perusahaan, dan DER Terhadap Profitabilitas Perusahaan. Diponegoro Journal of Management, 6.

Smith, K. (1980). Profitability Versus Liquidity Tradeoffs in Working Capital Management.

Solimun, A., \& Nurjannah. (2017). Metode Statistik Multivariant Pemodelan Persamaan Struktural (SEM) Pendekatan WarpPLS. Malang: UB Press. 
Suminar, M. T. (2015). Pengaruh Perputaran Persediaan, Perputaran Piutang dan Perputaran Kas Terhadap Profitabilitas Pada Perusahaan Sektor Industri Barang Konsumsi Yang Terdaftar Di BEI Periode 2008-2013. Jurnal Ilmiah Universitas Pandanaran, 1-19.

Susilawati, d. (2017). Pengaruh Perputaran Persediaan dan Perputaran Total Aset Terhadap Profitabilitas Pada PT Indofarmna (Persero) Tbk. STAR-Study \& Accounting Research, 16934482.

Syarief, M. E., \& Wilujeng, I. P. (2009). Cash Conversion Cycle dan Hubungannya dengan Ukuran Perusahaan, Profitabilitas dan Manajemen Modal Kerja. Jurnal Ekonomi Bisnis, 61-69.

Triono, D. C. (2014). Ekonomi Islam Madð̧hab Hamfara Jilid I. Jogjakarta: Irtikaz.

Zhuquan, A. I. (2015). Working Capital Management and Profitability Evidence from Firms Listed on Karachi Stock Exchange. International Journal of Business and Management, 231-235. 